\title{
Interesting Cognitive Logic of Vietnamese and English Perception Verbs
}

\author{
Phuong Nguyen Hoang \\ Faculty of Vietnamese Studies, University of Social Sciences and Humanities, Vietnam National University, Hochiminh City, Vietnam
}

\section{Email address:}

ling.dr.phuong@gmail.com, nguyenhoangphuong@hcmussh.edu.vn

\section{To cite this article:}

Phuong Nguyen Hoang. Interesting Cognitive Logic of Vietnamese and English Perception Verbs. International Journal of Language and Linguistics. Vol. 5, No. 4, 2017, pp. 95-98. doi: 10.11648/j.ij11.20170504.12

Received: May 6, 2017; Accepted: May 17, 2017; Published: July 11, 2017

\begin{abstract}
Each of the phenomena is perceived by human in certain specific ways from perception to cognition. The next step is the convert of cognitive information into language codes so that these information can be released to the object of communication, the receiver or the listener. Then, the listener receives codes and decodes them in order to understand the information from which he can perform a reverse process. That communication process must have its rules. To communicate successfully, to have mutual-understanding between objects of communication, we need to have a system of cognitive logic rules. Therefore, in this research paper, the author uses the cognitive linguistics analysis approach to investigate the interesting cognitive logic points of the basic perception verbs both in English (look, see, listen, hear, smell, taste and touch) and in Vietnames (nhì, nghe, ngửi, nếm, sò̀ and thấy). For research data, the author inspected and collected 3,946 sentences with perception verbs from two sets of English-Vietnamese, Vietnamese-English bilingual novels: The adventures of Sherlock Holmes and Love after war. As a result, what the author has achieved for this research question are how to understand negative cognitive meanings, how to interpret the true-false value of utterances with perception verbs, and some interesting cognitive logic rules we must apply in order to get the exact cognition of the utterances containing perception verbs.
\end{abstract}

Keywords: Perception, Cognition, Cognitive Logic, Negative Cognitive Meanings, True-False Value, Cognitive Logic Rules

\section{Introduction}

Logic is the science of forms and rules of thinking. It studies the essential relationship with regularity between things and phenomena of objective reality as well as between thoughts and ideas in human thinking and reasoning. $[4,5]$

Logic is a fulcrum in the study of natural language because between logic and natural language there are close ties. The objects of logic are generalized structures and rules of thinking. In the regime of logic, approaches to perceive the world are built. They are concepts, judgements, inference methods, stating hypothesis, proving, rejecting, etc. People are not able to think without using language. The concept is expressed in words; judgments are expressed in sentences, string of sentences. So, language is a tool for thinking. Language is also the most important tool to communicate. Communication is the process of transmitting and receiving information. In communication, people also inform, express ideas, and prove, convince, argue, question, doubt, reject, etc. i.e. thinking. Therefore, there are laws of words to express, reflect the thinking and receive information. [3, 15], [4, 15]

That's true. Every phenomena is perceived by human in certain specific ways from perception to cognition. The next step is the convert of cognitive information into language codes so that these information can be released to the object of communication, the receiver or the listener. Then, the listener receives codes and decodes them in order to understand the information from which he can perform a reverse process. That communication process must have its rules. To communicate successfully, to have mutualunderstanding between objects of communication, we need to have a system of cognitive logic rules.

For the group of perception verbs the author is investigating, their cognitive logic includes many extremely interesting points. For instance, consider the following example [1, 214-226]:

Mary sees every frog jump. (1)

Mary sees nobody dance. (2) 
For (1), everything is clear. However, for (2) there are more complex issues. With a sudden utterance as (2), we will have various ways of understanding it. They will be investigated clearly as followed.

\section{Negative Cognitive Semantics}

Negative cognitive semantics is a distinct and very interesting trait of the perception verbs if considered within the regime of cognitive logic. Nicholas and Daniel [1, 214226] have the following examples:

Mary sees every frog jump. (3)

Mary sees nobody dance. (4)

Every frog is seen by Mary to jump. (5)

There is nobody there, so, Mary can see nobody dance. (6)

There is nobody who Mary sees dance. (7)

There is somebody dance, however, Mary can't see any.

(8)

For (3, everything is clear. However, for (4) there are more complex issues. With a sudden utterance as (4), there will be up to three various ways of understanding it as in (6), (7) and (8).

The same phenomenon can be seen in Vietnamese when considering the following example.

Tôi chẳng thấy có gì đáng buồn cười trong chuyện này. (9)

(I do not see anything funny in this story.)

From (9) there can be the following interpretations:

Tôi thấy trong chuyện này không có gì đáng buồn cười. (10)

(I see that in this story there is nothing funny.)

Trong chuyện này có điểm đáng buồn cười nhưng tôi không thấy. (11)

(In this story there is something funny but I cannot see any.)

Những điểm mà tôi thấy trong chuyện này không đáng buồn cười. (12)

(Things that I can see in this story is not funny.)

In Vietnamese and English, the fact that utterances with perception verbs have cognitive polysemantic/ ambiguity as in examples (4) and (9) often happens. When used with a certain communication purpose, these utterances must be explained, added illustrations to clarify meaning by other factors as the context, the next utterances, etc. If not, it will be difficult to determine the semantics of communication which the speaker wants to convey. For instance, with the following example:

Trân không thấy người đàn ông đi ra. [III, 194] (13)

Tran did not see him going out. [IV, 184]

With an utterance just like this (13) only, whether that man did not come out will not be known and so, Trân didn't see him, or, that man did come out, but Trân couldn't see him.

The next interesting point is that with the same negative structure, however, the meaning interpretations of utterances with perception verbs is a big difference from those of other verbs. It can be seen that clearly in these below examples.

Ex:

Tôi có tiền. / Tôi không có tiền. (14)
I have money. / I don't have money.

Tôi thấy anh. / Tôi không thấy anh.(15)

I saw you. / I didn't see you.

Tôi thấy ở đó không có người.(16a) / Tôi không thấy ở đó có người.(16b)

I saw that there was nobody there. / I didn't see anybody there.

For (14) and (16a) it is sure that I don't have money. It can be interpreted that there is no money that I possess. However, for (15) there's no sureness that I didn't see you. because you weren't there. It's the same for (16b).

In general, the examples above shows that the perception verbs can have the ability to have cognitive polysemantic/ ambiguity. This happens due to the fact that upon this group of verbs, there is a great domination of perceptual competence. It determines the cognitive meaning of the utterances.

\section{The True - False Value}

The next point which is also quite interesting is the cognitive logic of the perception verbs belongs to both formal logic and informal logic. In many cases, the true false value doesn't play any role and has no meaning in determining whether an utterance is right or wrong.

Formal logic provides us the rules for the formation of concepts, judgements and especially the discursive approaches to conduct reasonable arguments on the judgements. A fundamental characteristic of formal logic is that each judgement has a certain truth value, i.e. every judgement is either right or wrong. And the discursive rules provides us approaches to conduct reasonable arguments in a way so that from the truth values of a number of given judgements, we can infer the truth value of the being viewed judgement.

Informal logic is a discipline which builds a logic to evaluate, interpret, analyze and construct arguments in everyday discourse as well as scientific discourse, from daily conversations, quarrels, debates, advertising, media comments, to political discourse, the scientific report... Informal logic includes both traditional logical inferences and informal inferences.[5, 3]

That's true. If considered in the field of cognitive semantics of the perception verbs, the true - false value, in many cases, plays no role and contributes no meaning in determining whether an utterance is right or wrong.

For example, with the followed utterance:

Trong ký ức tôi thấy tháp Eiffel chỉ mới xây dựng được một nửa thôi. (17)

(In my memory I saw that the Eiffel Tower had just been being built a half only.)

With this utterance, the true - false value of the fact that "tháp Eiffel chỉ mới xây dựng được một nửa thôi” (the Eiffel Tower had just been being built a half only) has no effect on determining whether the utterance (17) is right or wrong.

In communication reality, more of many other operations will be needed so that these utterances can be understood and 
people can perform language interactions, communicate with each other successfully. Such as the following case:

Hắn nhìn mãi mà không thấy có cây bút trên bàn. (18)

(He looked forever but didn't see a pen on the table.)

With this example, the fact whether there is a pen on the table or not has no effect on the true - false value of this utterance. And people can not fully understand all the semantic traits of this utterance if people have no information link, other perspective operations such asconnecting it to either of those two following cases:

Hắn đành qua phòng bên tìm. (19)

(He had to go to the next room to look for it.)

Hắn thật là sơ xuất. (20)

(He was really negligent.)

Those two just mentioned examples have added the assertion that the factor of perceptual competence has a significant domination over the cognitive semantics of the perception verbs.

\section{Interesting Cognitive Logic Rules}

To take into cognition a language expression containing perception verbs, we need to consider the relationships between the perceptor and the perceived. In many cases, the perceptor may not be the agent of the act of perception in the language expression.

Ex: -Nhung chị nhận ra ông nhìn chị với một vẻ chú ý đặc biệt, tuy kín đáo. [III, 58](21)

But she realized that he was looking at her with special interest, although discreet. [IV, 43]

In this case, the perceptor is chi / she but the agent of the act of perception is ong / he.

-Trong khi sắp xếp ghế, tôi thấy Bình nhìn Mi. [III, $140](22)$

When I was arranging the chairs, I noticed Binh looking at Mi. [IV, 121]

And in this case, the perceptor is tô / I but the agent of the act of perception is Binh.

-Hắn nhìn cũng được. (23)

He looks $O K$.

In this utterance, the subject is hắn / he, but the perceptor in this case is an agent outside the utterance, is implicitly understood in context. Hắn / he in this utterance is actually the object of the act of perception nhin (look).

Beside that, the cognitive mechanism of the perception verbs consists of three phases, three different stages or in other words, three different levels in the cognitive action. The scope and purpose of using the perception verbs to express things are also different in different situations. The cognitive processes which happen to different groups of perception verbs are not the same. Therefore, the cognitive semantics of the perception verbs are totally different in these three levels.

Ex:

Table 1. Levels of perception.

\begin{tabular}{lll}
\hline Level 1 & Level 2 & Level 3 \\
\hline Perception Activity & Perception Experience & Perception Cognition \\
Anh nhìn ra đưòng. (24) & Anh nhì tháy cái cây. (25) & Cái cây nhìn thật là to. (26) \\
(He looked out into the street.) & (He saw the tree.) & (The tree looked really big.) \\
\hline
\end{tabular}

The next interesting rule is that not seeing is before seeing. Let's consider the two following examples.

Ex:

Tôi thấy có nhà.(27)

I saw houses.

Tôi không thấy có nhà. (28)

I didn't see any houses.

If now those two utterances are matched together, then the correct order must be (28) to (27). It can never be in the reversed order.

Finally, these following cases of using means of linking in utterances containing perception verbs will be examined. Those utterances are in the following examples.

Ex:

Tôi đã ở đó. Tôi không thấy Mary. (29)

I was there. I didn't see Mary.

Tôi đã ở đó và tôi không thấy Mary. (30)

I was there and I didn't see Mary.

Tôi đã ở đó nhưng tôi không thấy Mary. (31)

I was there but I didn’t see Mary.

Tôi đã ở đó mà tôi không thấy Mary. (32)

That I was there, I did not see Mary.

Tôi đã ở đó thế mà tôi không thấy Mary. (33)

That I was there but I did not see Mary.
In the cases of (29) and (30), it can be understood that Mary wasn't there, I was there and I didn't see her. For cases of (32) and (33), it can be understood that Mary was there, I was there and I didn't see her. With the case of (31), it can be ambiguous. It can have two ways of understanding. The first way is that Mary wasn't there, I was there and I didn't see her. The second way is that Mary was there, I was there and I didn't see her. The fact that the meaning interpretations of those above utterances can vary is due to the usage of different means of linking in language.

\section{Conclusion}

Finally, through what the author has analyzed above, the following points can be drawn. In the view of cognitive logic, the semantics of the perception verbs not only depend on the cognitive rules of formal logic but also on those of informal logic. It also depends on the relationship between the perceptor and the perceived, and on the stages of perception - cognition. Especially, the perceptual competence can have a great domination over the cognitive semantics of the perception verbs. In order to interpret the exact meaning of utterances with perception verbs, the perspectives of the contexts should be based on. 


\section{Corpus}

I. C. D. Arthur, Những cuộc phiêu lưu của Sherlock

Holmes, Văn học, 2009.

II C. D. Arthur, The adventures of Sherlock Holmes,

The Project Gutenberg, 1999.

III. K. Wayne, H. A. Thái, Tình yêu sau chiến tranh, Hội

Nhà văn, 2004.

IV K. Wayne, H. A. Thai (edited), Love after war,

IV. Curbstone Press, 2003.

\section{References}

[1] Asher Nicholas M., Bonevac Daniel, "How extensional is extensional perception?", Linguistics and Philosophy 8, 203$228,1985$.

[2] Benthem Johan F. A. K. Van, Meulen G. B. Alice Ter, Handbook of Logic and Language, MIT Press, 1997.

[3] Dan Nguyen Duc, Logic and Vietnamese, Education Press, 1996.

[4] Dan Nguyen Duc, Introduction to Formal Logic, HCMc National University Press, 2005.
[5] Dan Nguyen Duc, "Introduction to Informal Logic", Journal of Language - Vietnam Linguistics Society, Vol. 7, 3-13, 2013.

[6] Douglas Walton, Informal Logic - A pragmatic approach, Cambridge University Press, 2008.

[7] Hegel Georg Wilhelm Friedrich, Science of Logic, Routledge, 2014.

[8] Jacqueline Guéron, Sentence and Discourse, Oxford University Press, 2015.

[9] Janusz Chmielewski, Language and Logic in Ancient China, Polska Akademia Nauk, Warszawa, 2009.

[10] Norris Christopher, On Truth and Meaning: Language, Logic and the Grounds of Belief, Continuum International Publishing Group, 2006.

[11] Ray Jackendoff, Paul Bloom, Karen Wynn, Language, Logic and Concepts, MIT Press, 2002.

[12] Torza Alessandro, Quantifiers, Quantifiers and Quantifiers: Themes in logic, metaphysics and language, Springer, 2015.

[13] Umberto Straccia, Foundations of Fuzzy Logic and Semantic Web Languages, CRC Press, 2013. 